\title{
Structural and morphological changes in the pancreas of rats after the introduction of a genetically modified product
}

\author{
Jasurbek AVOZMETOV ${ }^{1}$ \\ Bukhara State Medical Institute named after Abu Ali ibn Sino
}

\begin{tabular}{l} 
ARTICLE INFO \\
\hline Article history: \\
Received June 2021 \\
Received in revised form \\
20 June 2021 \\
Accepted 15 July 2021 \\
Available online \\
15 August 2021 \\
\hline
\end{tabular}

Keywords:

rats,

pancreas,

genetically modified

product.
ABSTRACT

Studying histological preparations obtained from the pancreas of animals of the experimental group (GMP), pathological changes were noted. Morphologically, there was marked hypertrophy and hyperplasia in the pancreas, increased secretory activity, stagnant fullness with hemorrhage sites. While in the animals of the control group and the majority of rats of the comparison group (90\%), there were no pathological deviations in the histological picture of the pancreas.

2181-1415/@ 2021 in Science LLC.

This is an open access article under the Attribution 4.0 International (CC BY 4.0) license (https://creativecommons.org/licenses/by/4.0/deed.ru)

\section{Genetik modifikatsiyalangan mahsulotni iste'mol qilingandan so'ng kalamushlarning oshqozon osti bezidagi strukturaviy va morfologik o'zgarishlar}

Kalit so'zlar:

kalamushlar,

oshqozon osti bezi,

genetik o'zgartirilgan

mahsulot.
ANNOTATSIYA

Eksperimental guruh (GMP) hayvonlarining oshqozon osti bezidan olingan gistologik preparatlarni o'rganishda patologik o'zgarishlar qayd etildi. Morfologik jihatdan oshqozon osti bezida gipertrofiya va giperplaziya, sekretor faollikning ortishi, qon ketish joylari bilan turg'un to'lishligi aniqlangan. Nazorat guruhi hayvonlarida va taqqoslash guruhi kalamushlarining ko'pchiligida (90\%) esa oshqozon osti bezining gistologik rasmida patologik og'ishlar bo'lmagan.

\footnotetext{
${ }^{1}$ Independent researcher, Bukhara State Medical Institute named after Abu Ali ibn Sino, Bukhara, Uzbekistan. E-mail: akwamarin80@gmail.com.
} 


\section{Структурные и морфологические изменения в поджелудочной железе крыс после введения генетически модифицированного продукта}

Ключевые слова:
крысы,
поджелудочная железа,
генно-
модифицированный
продукт.

\begin{abstract}
АННОТАЦИЯ
При изучении гистологических препаратов, полученных из поджелудочной железы животных опытной группы (ГМО), были отмечены патологические изменения. Морфологически отмечалась выраженная гипертрофия и гиперплазия поджелудочной железы, повышенная секреторная активность, застойная полнота с участками кровоизлияния. В то время как у животных контрольной группы и большинства крыс группы сравнения (90\%) патологических отклонений в гистологической картине поджелудочной железы не наблюдалось.
\end{abstract}

Much attention is currently being paid to the problems of using genetically modified organisms (GMOs) in food products, since there is a threat of their negative impact on human health and the environment [5].

Genetically modified organisms are living organisms that have intentionally changed the sequence of nucleic acids. These changes can be reduced to the introduction or removal of genetic fragments. Genetically modified (GM) products are completely identical to their natural samples in their main characteristics, such as color, smell and appearance.

Currently, GM plants are grown in 28 countries around the world, especially in the USA, Brazil, Argentina, India and Canada. The main GM crops are soy, corn, cotton, rapeseed, among them this process is more often applied mainly to soy $[2,9,13,15]$.

In addition to these products, rice, pumpkin, sunflower, peanuts, cassava and papaya are also grown as GM. Research on banana, raspberry, strawberry, cherry, pineapple, pepper, melon and watermelon continues. Among grain crops, only the herbicide resistance gene is transmitted to rice. There is no transgenic product for crops such as wheat or barley that would have a high economic value [6].

Genetic modification studies are also conducted on animals. In relation to animals, research is mainly aimed at increasing resistance to diseases, controlling their growth or changing the quality of wool and milk components. As a result of these studies, fish has become the only animal produced economically [16].

Some experts believe that the creation of GM food sources is an inevitable way to solve many nutrition and health problems. With the growth of the world's population, which, according to scientists, should reach 11 billion people by 2050, respectively, there is a need for a significant increase in world agricultural production, which is impossible without the creation of GMOs $[10,11,12]$.

The identification of undeclared GM food sources, as well as combinations of GMOs, is important to ensure the biological safety of food for the population $[1,3,4,7,14]$.

Currently, most GM products belong to the second safety class, given the presence in their composition of 1-2 proteins responsible for the manifestation of the desired trait that distinguishes the transgenic product from the traditional one [16]. 
In the Republic of Uzbekistan, the issues related to GM products have also not been finally resolved, in this regard, experimental studies to determine the effect of GM products on the organs and systems of the body are relevant and in demand.

The purpose of this study was to develop a method for evaluating the effect of a genetically modified product on the morphological parameters of the pancreas of laboratory animals in an experiment.

\section{MATERIALS AND METHODS}

GM soy (soy flour), grown abroad and imported to our country only for scientific research, was used as a GM product in the experiments. Using the polymerase chain reaction (PCR) method, the presence of the 35s+FMV promoter in the studied GM soy was revealed, which proves that the studied soy is a GM product. There was no such promoter in ordinary soy grown in our country and used for comparison - it is not a GM product.

Experimental studies were conducted on white mongrel rats. All laboratory animals were divided into 3 groups:

- experimental group - laboratory animals whose general vivarium standard diet included GM soy (soy flour) at a dose of 0.02-0.03 g per 1 rat weighing 160-180 g for 30 days $(n=30)$;

- comparison group - laboratory animals whose general vivarium standard diet included soy without GM (soy flour) at a dose of 0.02-0.03 g per 1 rat weighing 160-180 g for 30 days $(n=30)$; $(n=30)$.

- control group - laboratory animals kept only in the general vivarium standard diet

Experimental preclinical research of laboratory animals was carried out on the basis of the official letter of the Ethical Committee of the Ministry of Health of the Republic of Uzbekistan No. 4/14-1439 dated September 21, 2020 on the permission to conduct these studies (extract from the protocol No. 4 of the meeting of the Ethical Committee of the Ministry of Health of the Republic of Uzbekistan dated August 26, 2020).

Results and discussions. During macroscopic examination of the pancreas, no visual pathological changes were observed in all experimental animals of the control group $(n=30)$. Macroscopically noticeable changes were also not found in the animals of the comparison group (who received ordinary soy without GM together with food), only some rats of this group $(n=3 ; 10 \%)$ had gland hypertrophy. Whereas in almost all animals $(n=28$ from $n=30)$ of the experimental group, in whose diet GM soy was included, there was a change in the morphological parameters of the pancreas, expressed in hypertrophy and an increase in the size of the organ detected 30 days after the start of feeding.

Thus, macroscopically, in white mongrel rats that were on a standard diet (control group), the pancreas was without pathological abnormalities.

The next stage of our experiment was the study of the morphological features of the pancreas of white mongrel laboratory rats whose diet included soy with and without GM.

The results of the study obtained by us showed that there were no pathological deviations in the morphological picture of the pancreas in the experimental animals of the control group who were on a standard vivarium diet without soy (with and without GM) (Fig.1) 


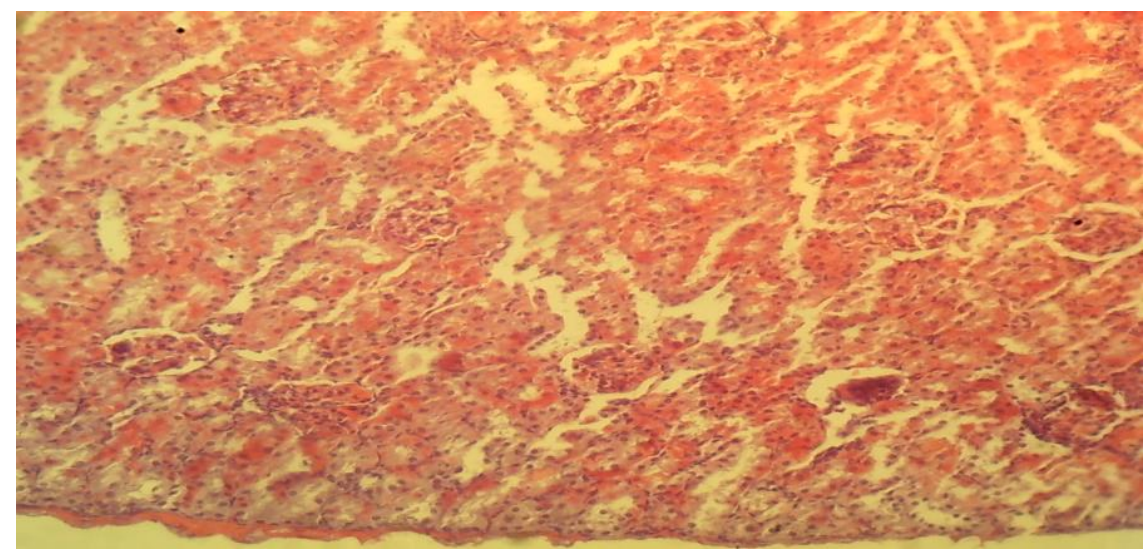

Fig. 1. Histological changes of the pancreas white outbred rats of the control group standard diet (staining with hematoxylin-eosin)

In laboratory animal comparison group that received a dietary Supplement of conventional soybeans without the GM, in 3 cases $(10 \%)$ showed minor changes in the pancreas (Fig.2) are characterized by moderate hypertrophy and hyperemia of the vessels.

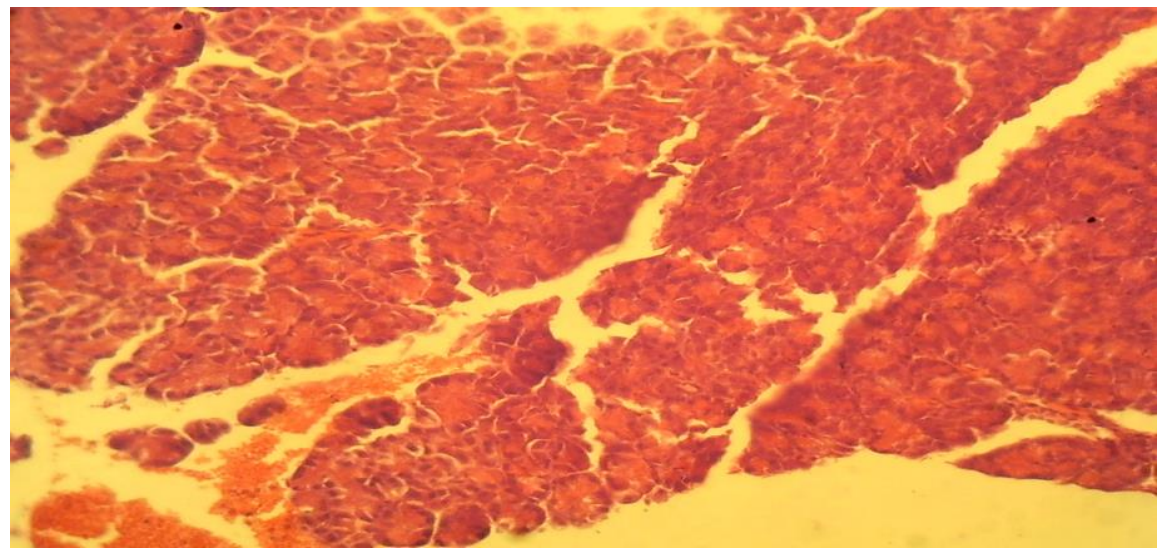

Fig. 2. Histological picture of the pancreas of a white mongrel rat of the comparison groupordinary soy, without GM (staining with hematoxylin-eosin)

The study of histological preparations of the pancreas of white mongrel rats of an experimental group of animals whose diet included GM soy showed that the morphological picture of the organ is fundamentally different from the data obtained in the above groups. Pathological changes were detected in almost all laboratory animals, which were characterized by pronounced organ hypertrophy, glandular hyperplasia, increased secretory activity, stagnant fullness with hemorrhage areas (Fig.3)

Thus, when studying histological preparations obtained from the pancreas of animals of the experimental group (GM soy), pathological changes were noted. Morphologically, there was marked hypertrophy and hyperplasia in the pancreas, increased secretory activity, stagnant fullness with hemorrhage sites. While in the animals of the control group and the majority of rats of the comparison group (90\%), there were no pathological deviations in the histological picture of the pancreas. 


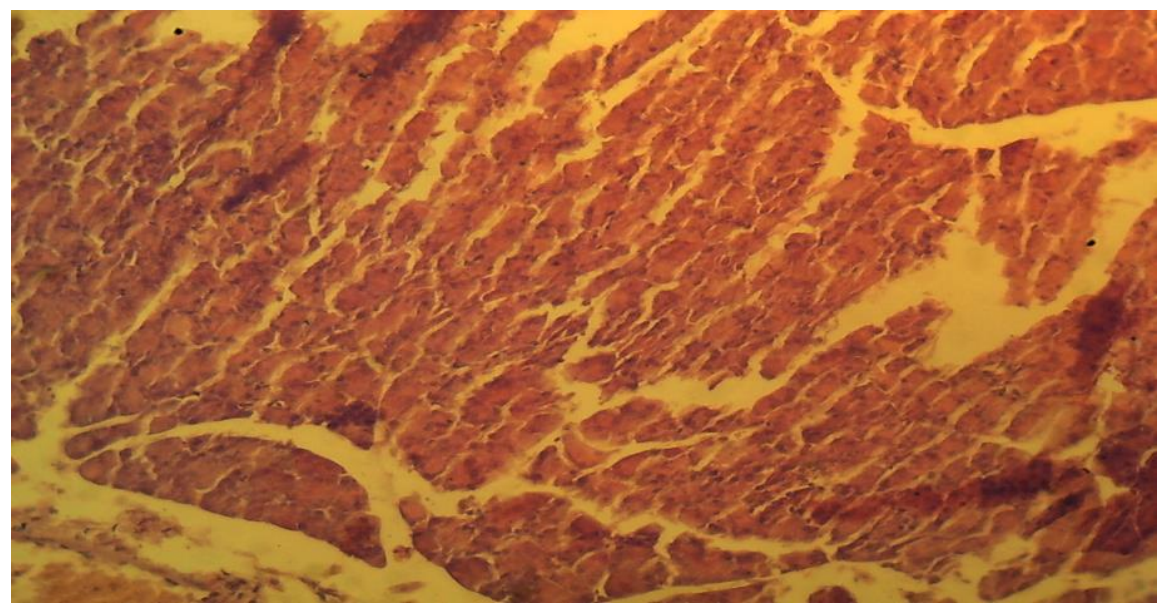

Fig. 3. Histological picture of the pancreas of a white mongrel rat of the experimental group-GM soy (staining with hematoxylin-eosin)

\section{CONCLUSIONS}

Macroscopically, in white mongrel rats that were on a standard diet (control group), the pancreas was without pathological abnormalities. Almost the same picture was observed in animals whose diet included ordinary soy (the comparison group), with the exception that $10 \%$ of them had some hypertrophy of this organ. And in laboratory animals, in the feed of which GM soy was added, in $93.3 \%$ of cases, pathological deviations associated with an increase in the organ during the observation period were visually noted.

There were pathological changes in the study of histological preparations from the pancreas of animals of the experimental group (GM soy). This fact was noted in the form of pronounced hypertrophy, hyperplasia of the glands, increased secretory function, congestive fullness and areas of hemorrhage. In contrast to the experimental group, there were no pathological deviations in the histological picture of the pancreas in the animals of the control group and the majority of the rats of the comparison group (90\%).

\section{REFERENCES:}

1. Akhrorova K.D. (2021). Morphofunctional properties of the lymphoid the structures of the spleen are normal and under the influence of various factors. Academicia: International interdisciplinary research journal, 11(1), 459-465.

2. Ahrorovna K.D., \& Jumaevich T.S. (2018). Topografic-anatomical features of lymphoid structures of the small intestine of rats in norm and against the backround of chronic radiation diseases. European science review, (9-10-2).

3. Ahrorovna K.D. (2021). Age-related morphofunctional features of changes in the thymus gland of experimental animals under the influence of genetically modified product. Middle European Scientific Bulletin, 11(1).

4. Ahrorovna K.D. (2021). Evaluation of the effect of a genetically modified product on the morphological parameters of the spleen of experimental animals. Academicia: An international multidisciplinary research journal, 11(1), 885-888.

5. Akhrorovna K.D. Medical Field Morphological Features of Human and Mammalian Spleen in Postnatal Ontogeny. Journal NX, 7(1), 252-256. 
6. Angers-Loustau A., Petrillo M., Bonfini L., Gatto F., Rosa S., Patak A., Kreysa J. JRC GMO-Matrix: a web application to support Genetically Modified Organisms detection strategies // BMC Bioinformatics. - 2014, - Vol. 15. - N1. - P. 417.

7. Bawa A.S., Anilakumar K.R. Genetically modified foods: safety, risks and public concerns-a review // J. Food Sci. Technol. - 2013. - Vol. 50. - N6. - PP. 1035-1046.

8. Chernysheva O.N., Sorokina E.Yu. Analytical methods for control of foodstuffs made from bioengineered plants // Nutrition issues. - 2013. - Vol. 82. - N3. - PP. 53-60.

9. Gerdes L., Busch U., Pecoraro S. GMO finder - a GMO screening database // Food Analytical Methods. - 2012. - Vol. 5. - N6. - PP. 1368-1376.

10. Gvozdkova I.A. Actual problems of development of perspective directions of ecological education and upbringing // University Bulletin. - 2014. - N2. - PP. 224-227.

11. Khasanova D.A. (2021). Morphofunctional changes in thymus gland of rats effected by genetically engineered crops. in advanced research: Problems and new approaches (PP. 120-125).

12. Khasanova D. (2020). Wirkung eines gen-modifizierten produkts auf die morphologischen parameter der strukturen der milz weißer ratten. Inter Conf.

13. Khasanova D.A., \& Asadova N.K. (2021). Morpho functional changes in thymus of white rats in acute stress. Academicia: an international multidisciplinary research journal, 11(1), 685-691.

14. Khasanova D.A., \& Teshaev S.J. (2018). Topografic-anatomical features of lymphoid structures of the small intestine of rats in norm and against the backround of chronic radiation diseases. European science review, (9-10-2), 197-198.

15. Morisset D., Novak P.K., Zupanic D., Gruden K., Lavrac N., Zel J. GMOeek: a user friendly tool for optimized GMO testing // BMC Bioinformatics. - 2014. - Vol. 15. - N1. - P. 258.

16. Mukhammadiyeva G.F., Karimov D.O., Dolgikh O.V., Krivtsov A.V., Mazunina A.A. Genetically modified food products: peculiarities of genetic identification // Health Risk Analysis. - 2018. - N4. - PP. 75-80. 